\title{
Gene expression profiling in the lung tissue of cynomolgus monkeys in response to repeated exposure to welding fumes
}

\author{
Jeong-Doo Heo $\cdot$ Jung-Hwa Oh $\cdot$ Kyuhong Lee $\cdot$ \\ Choong Yong Kim · Chang-Woo Song • \\ Seokjoo Yoon · Jin Soo Han • Il Je Yu
}

Received: 14 September 2009/Accepted: 28 October 2009/Published online: 20 November 2009

(C) The Author(s) 2009. This article is published with open access at Springerlink.com

\begin{abstract}
Many in the welding industry suffer from bronchitis, lung function changes, metal fume fever, and diseases related to respiratory damage. These phenomena are associated with welding fumes; however, the mechanism behind these findings remains to be elucidated. In this study, the lungs of cynomolgus monkeys were exposed to MMA-SS welding fumes for 229 days and allowed to recover for 153 days. After the exposure and recovery period, gene expression profiles were investigated using the Affymetrix GeneChip ${ }^{\circledR}$ Human U133 plus 2.0. In total, it was confirmed that 1,116 genes were up-or downregulated (over 2 -fold changes, $P<0.01$ ) for the T1
\end{abstract}

Electronic supplementary material The online version of this article (doi:10.1007/s00204-009-0486-z) contains supplementary material, which is available to authorized users.

J.-D. Heo $\cdot$ K. Lee $\cdot$ C.-W. Song

Division of Inhalation Toxicology, KIT Jeongeup Campus,

1051, Shinjeong-dong, Jeongeup, Jeollabuk-do, Korea

J.-H. Oh · S. Yoon

Division of Research and Development,

Korea Institute of Toxicology,

19 Shinsung-ro, Yuseong, Daejeon, Korea

C. Y. Kim

Division of Toxicology, Korea Institute of Toxicology,

19 Shinsung-ro, Yuseong, Daejeon, Korea

\section{J. S. Han (ه)}

Department of Laboratory Animal Medicine,

College of Veterinary Medicine, Konkuk University,

1 Hwayang-dong, Gwangjin-gu, Seoul 143-701, Korea

e-mail: LABVET@konkuk.ac.kr

\section{J. Yu (ه)}

Fusion Technology Research Institute, Hoseo University, 165 Sechul-ri, Baebang-myun, Asan 336-795, Korea e-mail: u1670916@chollian.net $\left(31.4 \pm 2.8 \mathrm{mg} / \mathrm{m}^{3}\right)$ and $\mathrm{T} 2\left(62.5 \pm 2.7 \mathrm{mg} / \mathrm{m}^{3}\right)$ dose groups. Differentially expressed genes in the exposure and recovery groups were analyzed, based on hierarchical clustering, and were imported into Ingenuity Pathways Analysis to analyze the biological and toxicological functions. Functional analysis identified genes involved in immunological disease in both groups. Additionally, differentially expressed genes in common between monkeys and rats following welding fume exposure were compared using microarray data, and the gene expression of selected genes was verified by real-time PCR. Genes such as CHI3L1, RARRES1, and CTSB were up-regulated and genes such as CYP26B1, ID4, and NRGN were down-regulated in both monkeys and rats following welding fume exposure. This is the first comprehensive gene expression profiling conducted for welding fume exposure in monkeys, and these expressed genes are expected to be useful in helping to understand transcriptional changes in monkey lungs after welding fume exposure.

Keywords MMA-SS welding fumes - Monkey · Gene expression profiling

\section{Introduction}

Welding fume exposure occurs in many industrial fields. It is estimated that approximately 800,000 full-time welders were exposed to welding fumes during welding. If welders working at part-time jobs are included, many more welders may be exposed worldwide (Sferlazza and Beckett 1991). Welding fumes are created when metal is united with pressure and heat. During this process, many injurious factors are generated, including welding fumes, ozone, and gases, such as nitric oxide and steam vapor, as well as ionizing and 
non-ionizing radiation (Harris 2002; Burgess 1995). In particular, welding fume components, such as $\mathrm{Fe}, \mathrm{Cr}$, and $\mathrm{Ni}$, can cause pulmonary disease (Antonini et al. 2004).

Many studies have been conducted regarding the injurious factors generated during the welding process. These studies have focused on the toxicological operation of the lungs during welding fume exposure. Furthermore, the correlation between the injurious components of welding fumes including pulmonary diseases, such as siderosis, immunosuppression, and lung cancer, has also been studied (Antonini et al. 2003). Acute exposure to welding fumes induces metal fume fever (Mueller and Seger 1985) and reversible respiratory symptoms (El-Zein et al. 2003; Wolf et al. 1997). Moreover, welding fumes induce asthma in welders, and there is an increase in the inflammatory transition of the lungs, such as in chronic bronchitis (ElZein et al. 2003). These studies show that exposure to a high concentration of welding fumes over the long term induces pulmonary diseases. Yu et al. established that a stainless steel welding fume generation system produced pneumotoxic effects, and lung fibrosis was induced by exposure to chronic and high concentrations of welding fumes in Sprague-Dawley rats (Yu et al. 2001, 2003a, b, 2004). Although the toxicological effects of welding fumes on lung injury have been studied using animal models, information about the molecular and genetic events that cause lung injury or trigger the inflammatory response to prevent injury is lacking.

Recently, microarray analysis has been used in toxicology to interpret the toxicological effects at the transcriptional level and to identify genetic biomarkers in specific target cells or tissues (Young 2002, Chung et al. 2004; Oda et al. 2005; Powell et al. 2006). Moreover, phenotype-anchored gene expression profiles suggest that various toxicological endpoints or diseases can be classified or predicted by gene expression patterns (Alizadeh et al. 2000; Bittner et al. 2000). Gene expression analysis has been used to investigate peripheral blood mononuclear cells in which pneumoconiosis symptoms were caused in a rat model after a 30-day exposure to welding fumes (Rim et al. 2004). In a previous study, we also investigated gene expression profiling in lung injury in Sprague-Dawley rats after welding fume exposure and recovery (Oh et al. 2007). Although gene expression profiling has been performed in animal models, there are differences in transcriptomic regulation between humans and animals.

Thus, in this study, the cynomolgus monkey model, the genome of which is highly homologous to the human genome, was used to investigate gene expression profiling of lung injury following welding fume exposure. Gene expression profiling using a monkey model may reduce interspecies variances between an animal model and humans and help to address the toxicity of welding fume exposure in the human lung. We also compared gene expression profiles between the rat and the monkey to analyze the genetic level correlation and assess the reliability of expression patterns in the monkey model, because we used a limited number of monkeys in the study. This is the first comprehensive report on gene expression in the lungs of monkeys after welding fume exposure and recovery. This study provided molecular insights in the lung tissues when welding fumes were repeatedly infiltrated.

\section{Materials and methods}

\section{Generation of MMA-SS welding fumes}

The welding fumes were generated using an automatic robotic arm as a holding support for the welding rod (KST 308, $2.6 \mathrm{~mm} \times 300 \mathrm{~mm}$, Korea Welding Electrode Co. Ltd, Seoul, Korea) as previously described (Sung et al. 2007; Park et al. 2007). When the robotic arm approached the base stainless steel plate (SUS 304, $2.5 \mathrm{~cm}$ thick) in a zigzag motion, an arc was produced and the rod was consumed, generating welding fumes. The fumes were then moved into exposure chambers (whole-body type, each $1.5 \mathrm{~m}^{3}$, Dusturbo, Seoul, Korea) that were rectangular in shape and made of metal with a Plexiglas window. Each chamber accommodated two monkey cages, and the total volume occupied by the two monkeys in a chamber was estimated as $1.3 \%$. The chambers were equipped with HEPA filters to provide purified air to the exposure chambers. The welding fumes in the chamber were sampled using a personal sampler (MSA 484107, Pittsburgh, PA) at a flow rate of $21 / \mathrm{min}$. The metal composition of the welding fume particulates captured on membrane filters (pore size $0.8 \mu \mathrm{m}, 37 \mathrm{~mm}$ diameter, Millipore AAWP 03700, Bedford MA, USA) was analyzed for metal composition with an inductively coupled plasma analyzer (Thermojeralash, IRIS, Houston, TX, USA), using the NIOSH method 7300 (1999). Nitrous fumes, $\mathrm{O}_{3}$, and $\mathrm{NO}_{2}$ were all measured using Drager tubes (catalog numbers 6733181, $\mathrm{CH}$ 31001, and $\mathrm{CH} 30001$, respectively) and sampled by stroking a gas detector pump (6400000, Drager, Lubeck, Germany), according to the manufacturer's directions $1 \mathrm{~h}$ after the welding fume exposure began. An Anderson sampler (AN-200, Shibata, Tokyo, Japan) was used to measure the mass media aerodynamic diameters of the welding fumes. The flow rate was $28.3 \mathrm{l} /$ $\mathrm{min}$, and the samples were collected for $5 \mathrm{~min}$.

Exposure to welding fumes

Monkeys were exposed to the welding fumes as described previously (Sung et al. 2007; Park et al. (2007). Six 
$63 \pm 5$-month-old, male cynomolgus monkeys (3.7 \pm $0.7 \mathrm{~kg}$; Macaca fascicularis) were purchased from the Yunnan National Laboratory Primate Center (China) and acclimated for a 3-month period. The sequestered animal room was maintained at a temperature of $23 \pm 3^{\circ} \mathrm{C}$ and a relative humidity of $55 \pm 10 \%$, with air ventilation $10-20$ times/h, a light intensity of 150-300 lux, and a 12/12-h light/dark cycle ( 8 am to $8 \mathrm{pm}$ ). Throughout the study, the monkeys were individually housed in stainless steel wire cages $(660 \mathrm{~W} \times 8001 \times 850 \mathrm{H} \mathrm{mm})$ and fed a standard monkey diet (Oriental Yeast Co., Tokyo, Japan). No dietary supplement, such as fruit, was provided. Ultraviolet-irradiated and filtered municipal tap water was provided to the animals ad libitum. All animals were cared for in accordance with the principles outlined in the "Guide for the Care and Use of Laboratory Animals," an NRC publication (ILAR 1996). The monkeys were randomly assigned to three groups (unexposed, $n=2$; low dose, $n=2$; and high dose, $n=2$ ), using the Path/Tox System (Version 4.2.2, Xybion Medical Systems Corporation, Cedar Knolls, NJ, USA), and exposed to welding fumes for $2 \mathrm{~h} /$ day, 5 days/week (1:30 pm to $3: 30 \mathrm{pm})$ in the exposure chambers. Before initiating the inhalation exposure, the monkeys were taken out of their normal cages and housed in individual wire cages $(450 \mathrm{~W} \times 6001 \times 460 \mathrm{H} \mathrm{mm})$ that were specially designed for the inhalation experiment. In total, four monkeys, two in each chamber, were concurrently exposed during each 2-h exposure period. One monkey was used in each test group and recovery group. The control animals were not placed in the inhalation chamber; they remained in the cage during the 2-h exposure period. Food and water were not provided during the 2-h exposure, and the monkeys were taken out of the chambers at the end of the 2-h exposure. The time-weighted average (TWA) concentrations for the exposure doses were $31.4 \pm 2.8 \mathrm{mg} / \mathrm{m}^{3}$ (T1) and $62.5 \pm 2.7 \mathrm{mg} /$ $\mathrm{m}^{3}$ (T2) total suspended particulates per $2 \mathrm{~h}$. The target concentrations were achieved by varying the flow rates, by adjusting the dampers. Necropsies were performed after the 229 days of exposure and after the 153-day recovery period.

\section{Histopathology}

Lung samples collected from exposed, recovered, and control monkey were fixed in $10 \%$ neutral buffered formalin and embedded in paraffin. Sections $(4 \mu \mathrm{m})$ were cut using a microtome (RM2165; Leica, Wetzlar, Germany), stained with hematoxylin and eosin, and examined under a light microscope (E400; Nikon, Tokyo, Japan).

\section{Isolation of RNA}

A portion of the lung samples was homogenized in Trizol reagent (Invitrogen, Carlsbad, CA, USA), and the isolated total RNA was repurified using an RNeasy mini kit (Qiagen, Valencia, CA, USA), according to the manufacturer's protocol. Total RNA was quantified using a NanoDrop spectrophotometer (NanoDrop Technologies, Montchanin, DE, USA), and the quality of RNA was evaluated using a 2100 Bioanalyzer (Agilent Technologies, Palo Alto, CA, USA) for DNA chip experiments.

\section{Microarray analysis}

The Affymetrix GeneChip ${ }^{\circledR}$ Human Genome U133 Plus 2.0 array was used for the microarray analysis. Sample labeling, microarray hybridization, washing, and scanning were performed according to the manufacturer's protocol (Affymetrix, Santa Clara, CA, USA). Microarray experiments for each exposure and recovery group were duplicated and, in total, twelve arrays were used. The preprocessing procedure for the cell intensity files (CEL) and the following microarray analyses were performed using GenPlex software (Istech Inc., Goyang, Korea). Data were normalized using global scale normalization. The differentially expressed genes in the each dose group of 229-day welding fume exposure group and the 153-day recovery group were selected based on the fold change and results from the Student's $t$-test (over 2 -fold and $P<0.01$ ), compared with the corresponding controls. Hierarchical clustering was also performed with the centered Pearson's correlation, using these selected genes, based on the complete linkage and distance matrix. Differentially expressed genes in the 229-day welding fume exposure group and the 153-day recovery group were imported into Ingenuity Pathways Analysis (IPA; Ingenuity Systems, Redwood, CA, USA), and the biological functions and toxicology were analyzed. Genes commonly deregulated during welding fume exposure between the monkeys and the rats were analyzed using microarray data for the 229-day welding fume exposure group of monkeys and those for the 30-day welding fume exposure group of rats, previously reported by Oh et al. (2007). In rat model for welding fume exposure, rats for $\mathrm{T} 1$ and $\mathrm{T} 2$ dose group were exposed to $51.4 \pm 2.89 \mathrm{mg} / \mathrm{m}^{3}$ and $84.63 \pm 2.87 \mathrm{mg} / \mathrm{m}^{3}$, respectively, for $2 \mathrm{~h}$ per day for up to 30 days (Oh et al. 2007). Lower cutoff threshold (over 1.3 -fold and $P<0.01$ ) for selecting the differentially expressed genes was performed to compare deregulated genes between two species exposed to welding fumes. Based on fold change and statistical significance, 1,342 and 4,881 differentially expressed genes were selected in the monkey and rat exposure groups, respectively. Among the 1,342 differentially expressed genes in monkeys, 534 genes with a gene symbol were selected to compare with those of the rat model. The selected genes were annotated based on NetAffx (http://www.Affymetrix.com). 


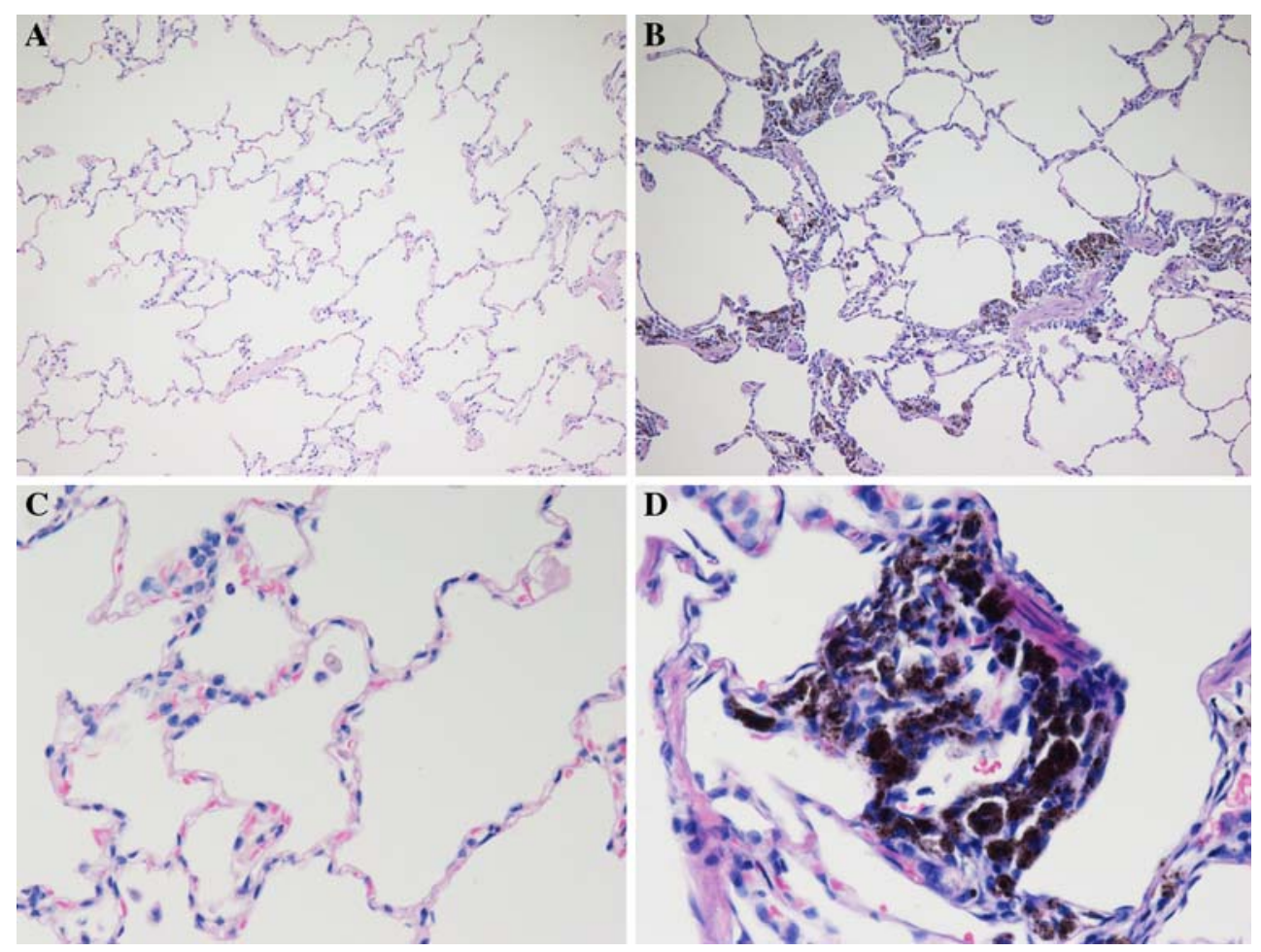

Fig. 1 Light micrographs of monkey lungs after 229 days of welding fume exposure a control $(\times 100), \mathbf{b} \mathrm{T} 2 \mathrm{dose}\left(62.5 \pm 2.7 \mathrm{mg} / \mathrm{m}^{3}, \times 100\right), \mathbf{c}$ Control $(\times 400), \mathbf{d}$ T2 dose $\left(62.5 \pm 2.7 \mathrm{mg} / \mathrm{m}^{3}, \times 400\right)$

\section{Quantitative real-time RT-PCR}

Gene transcripts were detected and quantified using SYBR Green (QuantiTect SYBR Green PCR Master Mix; Qiagen), according to the manufacturer's instructions, on a Rotor-Gene 6000 real-time rotary analyzer (Corbett Research, Sydney, Australia). Primers were designed using the Primer3 software (http://frodo.wi.mit.edu/); the primer sequences are presented in Supplemental Table 1. A melting curve analysis was performed on all amplified products to ensure the specificity and integrity of the PCR products. The Gapdh level was used as an internal control, and fold changes were calculated according to the $2^{-\Delta \Delta C T}$ method (Livak and Schmittgen 2001).

\section{Results}

Exposure to welding fumes and histopathology

To induce lung damage caused by welding fumes, monkeys were exposed to welding fumes at dose levels of $31.4 \pm 2.8 \mathrm{mg} / \mathrm{m}^{3}$ (T1 dose) and $62.5 \pm 2.7 \mathrm{mg} / \mathrm{m}^{3}$ (T2 dose) for 229 days and allowed to recover for 153 days. After the recovery period, serum biochemical and pathological examinations were performed. Serum biochemistry showed that no significant change was noticed (data not shown) in lymphocytes or neutrophils during the welding fume exposure. Histopathology showed that significant lung damage, such as pulmonary fibrosis, was not observed in either the 229-day exposure group or the 153-day recovery group. However, the lung tissues were infiltrated with welding fumes in both the $\mathrm{T} 1$ and $\mathrm{T} 2$ dose groups (Fig. 1). A similar severity of infiltration was interestingly observed in the 153-day recovery group (data not shown), even though after long-term recovery period (153-day).

Differentially expressed genes in the monkey lungs of the welding fume-exposed and recovery groups

For the microarray analysis, differentially expressed genes were selected from the monkey lung tissues in the welding fume exposure and recovery groups. In the exposure and recovery group, 669 (T1 dose, 365; T2 dose, 370) and 489 (T1 dose, 309; T2 dose, 239) genes were up- or downregulated, respectively. Hierarchical clustering was performed; the results showed that samples were clustered in each dose group, many genes were commonly deregulated in both dose groups, and several genes were clustered specifically to each dose group (Fig. 2). The top 20 highly deregulated genes from the exposure group are shown in Table 1. Genes involved in signaling pathways ( $D G K B$, PIAS2, AXIN2), metal ion binding (TRIM2), DNA binding (HIST1, H2BC), and metabolism (CHIT1) were up- 

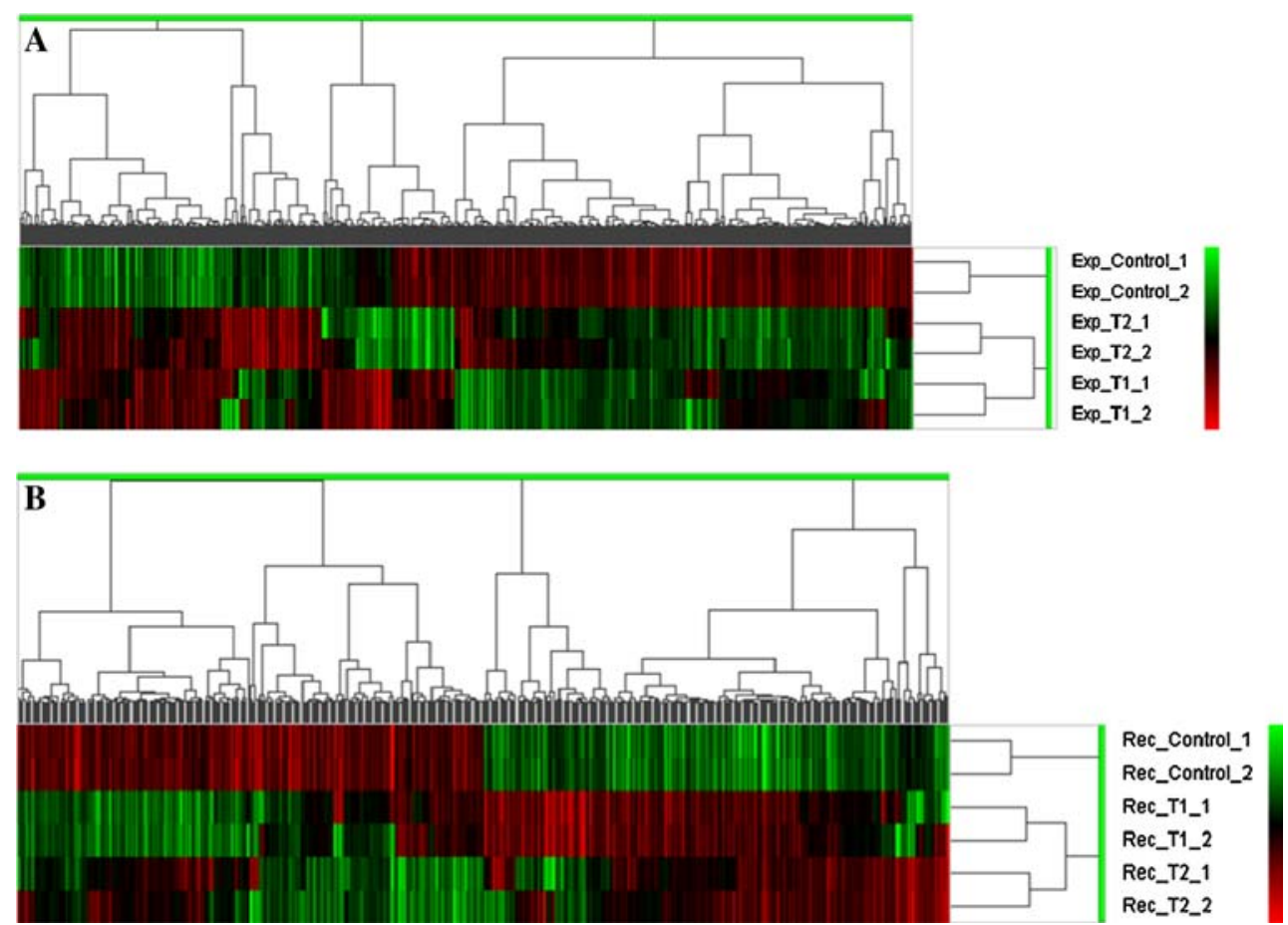

Fig. 2 Hierarchical clustering of differentially expressed genes in monkey lungs from the welding fume exposure a and recovery $\mathbf{b}$ groups

regulated in the exposure group, although most genes were not functionally annotated. In contrast, genes involved in transport (ABCA13, STEAP2, KCNH2, KCNV1), transcription (236231_at, ZNF738, HEY2), cell adhesion (ACTN2), rRNA processing (ADAT2), and protein binding (SLITRK6) were down-regulated in the exposure group.

In the recovery group, genes involved in tRNA aminoacylation (IGL@, TARS), antigen presentation or immune response (HLA-DPB1, IGHM, GAGE12F), cell differentiation or development (THOC5, FNDC3A, DOCK7), metabolism (CHIT1, CPT1A), and apoptosis (240890_at, $J A K 2$ ) were up-regulated, whereas genes involved in heat shock protein binding (DNAJC6, NTRK2, DNAJC10), signal transduction (RGS4), proteolysis (DPP10), antigen presentation (HLA-DPAI), cell cycle arrest (GAS2L3), transcription (ZNF483), and development (RICTOR) were down-regulated (Table 2).

Functional classification of differentially expressed genes in the welding fume exposure and recovery groups

The molecular mechanisms of these selected 669 and 489 genes from the exposure and recovery groups, respectively, were analyzed using IPA. As shown in Table 3, the results confirmed changes in the expression of genes in the exposure group involved in immunological disease, genetic disorders, cancer, organism injury and abnormalities, and inflammatory diseases. In the recovery group, genes involved in cancer, immunological diseases, and inflammatory diseases ranked high. Among these categories, highly regulated genes related to immunological and inflammatory disease were represented in Table 4. As shown in Table 4, PPID, CFLAR, CPTIA, and INSR for up-regulated genes and KLKB1, ATM, RAG1, UBASH3A, $I G K C$, and PTPN22 for down-regulated genes were consistently regulated in both exposure and recovery group.

When the molecular and cellular functions were analyzed, changes in the expression of genes involved in cellular growth, proliferation, and development were observed in the exposure group. Changes in the expression of genes involved in cellular growth, proliferation, and the cell cycle were also observed in the recovery group. In the analysis of toxicological functions, changes in genes involved in the G1/S transition of the cell cycle, TR/RXR activation, and hepatic fibrosis were identified in both the exposure and recovery groups. In particular, changes in genes involved in gene regulation mechanisms by peroxisome proliferation, RAR activation, and oxidative stress response mediated by Nrf2 were identified in the recovery group (Fig. 3).

Commonly deregulated genes in the lungs of monkeys and rats after welding fume exposure

To compare the results from the gene expression pattern in monkey lung tissues exposed to welding fumes with those seen in rats, the expression level of 534 genes with 
Table 1 Differentially expressed genes in monkey lungs from welding fume exposure group

\begin{tabular}{|c|c|c|c|c|}
\hline \multirow{2}{*}{$\begin{array}{l}\text { Gene_symbol } \\
\text { /probe ID }\end{array}$} & \multirow[t]{2}{*}{ Gene_title } & \multirow[t]{2}{*}{ RefSeq ID } & \multicolumn{2}{|c|}{ Fold change (Log 2) } \\
\hline & & & Exp_T1 & Exp_T2 \\
\hline \multicolumn{5}{|c|}{ Up-regulated genes in the exposure group } \\
\hline XIST & $\mathrm{X}$ (inactive)-specific transcript & NR_001564 & 3.28 & 8.43 \\
\hline TMED6 & Transmembrane emp24 protein transport domain containing 6 & NM_144676 & 3.65 & 5.10 \\
\hline SFRS4 & Splicing factor, arginine/serine-rich 4 & NM_005626 & 2.28 & 5.00 \\
\hline 1556192_x_at & Full-length insert cDNA clone YR55D08 & - & 4.17 & 4.58 \\
\hline 242830_at & Unknown & - & 2.49 & 4.58 \\
\hline$D G K B$ & Diacylglycerol kinase, beta $90 \mathrm{kDa}$ & NM_004080 & 2.36 & 4.52 \\
\hline TRIM2 & Tripartite motif-containing 2 & NM_015271 & 0.38 & 4.48 \\
\hline EML5 & Echinoderm microtubule-associated protein like 5 & NM_183387 & 3.90 & 4.35 \\
\hline 244388_at & Transcribed locus & - & 3.24 & 4.06 \\
\hline C5orf 28 & Chromosome 5 open reading frame 28 & NM_022483 & 4.74 & 4.05 \\
\hline 1564299_at & CDNA FLJ33307 fis, clone BNGH42004076 & - & 2.91 & 4.01 \\
\hline 1566836_at & CDNA clone IMAGE:5302735 & - & 3.53 & 3.89 \\
\hline$H I S T 1 H 2 B C$ & Histone cluster $1, \mathrm{H} 2 \mathrm{bc}$ & NM_003526 & 4.08 & 3.80 \\
\hline LOC339260 & Hypothetical protein LOC339260 & - & 1.58 & 3.65 \\
\hline NHSL1 & NHS-like 1 & XM_496826 & 2.75 & 3.63 \\
\hline C6orf201 & Chromosome 6 open reading frame 201 & NM_001085401 & 3.25 & 3.61 \\
\hline PIAS2 & Protein inhibitor of activated STAT, 2 & NM_004671 & 1.17 & 3.58 \\
\hline AXIN2 & Axin 2 (conductin, axil) & NM_004655 & 4.03 & 3.49 \\
\hline CHIT1 & Chitinase 1 (chitotriosidase) & NM_003465 & 2.92 & 3.32 \\
\hline 233010_at & CDNA FLJ14313 fis, clone PLACE3000341 & - & 3.67 & 3.30 \\
\hline \multicolumn{5}{|c|}{ Down-regulated genes in the exposure group } \\
\hline OVOS 2 & Ovostatin 2 & NM_001080502 & -6.04 & -5.85 \\
\hline$A B C A 13$ & ATP-binding cassette, sub-family A (ABC1), member 13 & NM_152701 & -3.64 & -5.77 \\
\hline 236945_at & Unknown & - & -1.89 & -5.68 \\
\hline GPATCH2 & G-patch domain containing 2 & NM_018040 & -0.20 & -5.04 \\
\hline C20orf19 & Chromosome 20 open reading frame 19 & NM_018474 & -0.30 & -4.99 \\
\hline 242818_x_at & Transcribed locus & - & -0.66 & -4.95 \\
\hline$T M E F F 2$ & Transmembrane protein with EGF-like and two follistatin-like domains 2 & NM_016192 & -1.05 & -4.91 \\
\hline$K L K B 1$ & Kallikrein B, plasma (Fletcher factor) 1 & NM_000892 & -0.32 & -4.30 \\
\hline ACTN2 & Actinin, alpha 2 & NM_001103 & -2.90 & -4.03 \\
\hline 236231_at & Unknown & - & -2.14 & -4.01 \\
\hline 1569772_x_at & CDNA clone IMAGE: 4824424 & - & -3.11 & -3.98 \\
\hline ADAT2 & Adenosine deaminase, tRNA-specific 2, TAD2 homolog $($ S. cerevisiae $)$ & NM_182503 & -2.37 & -3.83 \\
\hline 243548_x_at & Transcribed locus & - & -1.72 & -3.75 \\
\hline ZNF738 & Zinc finger protein 738 & XR_015756 & -2.76 & -3.72 \\
\hline SLITRK6 & SLIT and NTRK-like family, member 6 & NM_032229 & -1.83 & -3.69 \\
\hline$H E Y 2$ & Hairy/enhancer-of-split related with YRPW motif 2 & NM_012259 & -2.65 & -3.66 \\
\hline STEAP2 & Six transmembrane epithelial antigen of the prostate 2 & NM_001040665 & -0.74 & -3.64 \\
\hline TEX12 & Testis expressed 12 & NM_031275 & -2.40 & -3.57 \\
\hline $\mathrm{KCNH} 2$ & Potassium voltage-gated channel, subfamily $\mathrm{H}$ (eag-related), member 2 & NM_000238 & -1.92 & -3.52 \\
\hline KCNV1 & Potassium channel, subfamily $\mathrm{V}$, member 1 & NM_014379 & -2.57 & -3.48 \\
\hline
\end{tabular}

Fold change was calculated with relative average value of 2 arrays in each group comparing to corresponding controls and values were represented with $\log 2$

identical gene symbols were compared as described in the "Materials and methods" section. Of 534 monkey genes that showed changes in lung tissue, 76 matched changes in rats (15\%). Among them, 39 were identified as up-regulated or down-regulated in both monkeys and rats $(51 \%$; Table 5). Most of these genes in common were down- 
Table 2 Differentially expressed genes in monkey lungs from welding fume recovery group

\begin{tabular}{|c|c|c|c|c|}
\hline \multirow[t]{2}{*}{ Gene_symbol/probe ID } & \multirow[t]{2}{*}{ Gene_title } & \multirow[t]{2}{*}{ RefSeq ID } & \multicolumn{2}{|c|}{ Fold change $(\log 2)$} \\
\hline & & & Rec_T1 & Rec_T2 \\
\hline \multicolumn{5}{|c|}{ Up-regulated genes in the recovery group } \\
\hline IGL@ & Immunoglobulin lambda locus & - & 4.63 & 4.92 \\
\hline 1557452_at & Full-length insert cDNA clone ZC19A03 & - & 5.15 & 4.64 \\
\hline$H L A-D P B 1$ & Major histocompatibility complex, class II, DP beta 1 & NM_002121 & 4.53 & 4.60 \\
\hline THOC5 & THO complex 5 & NM_001002877 & 1.59 & 4.12 \\
\hline$I G H M$ & Immunoglobulin heavy constant mu & - & 2.66 & 3.94 \\
\hline C6orf12 & Chromosome 6 open reading frame 12 & XM_001132906 & 4.18 & 3.88 \\
\hline$F N D C 3 A$ & Fibronectin type III domain containing $3 \mathrm{~A}$ & NM_001079673 & 3.65 & 3.81 \\
\hline 1561906_at & Homo sapiens, clone IMAGE:3626122 & - & 3.93 & 3.81 \\
\hline MRPLA4 & Mitochondrial ribosomal protein L44 & NM_022915 & 1.99 & 3.75 \\
\hline CHIT1 & Chitinase 1 (chitotriosidase) & NM_003465 & 2.45 & 3.73 \\
\hline DOCK7 & Dedicator of cytokinesis 7 & NM_033407 & 2.79 & 3.73 \\
\hline НОХА9 & Homeobox A9 & NM_152739 & 1.55 & 3.70 \\
\hline 240890_at & CDNA clone IMAGE:5216666 & - & 2.56 & 3.65 \\
\hline CPT1A & Carnitine palmitoyltransferase 1A (liver) & NM_001031847 & 2.93 & 3.63 \\
\hline$T A R S$ & Threonyl-tRNA synthetase & NM_152295 & 4.09 & 3.56 \\
\hline 1569727_at & Homo sapiens, similar to hypothetical gene LOC130797 & - & 3.12 & 3.51 \\
\hline$G A G E 12 F$ & $\mathrm{G}$ antigen 6 & NM_001098405 & 3.57 & 3.42 \\
\hline LOC731851 & Hypothetical protein LOC731851 & XM_001131041 & 3.69 & 3.37 \\
\hline$J A K 2$ & Janus kinase 2 (a protein tyrosine kinase) & NM_004972 & 3.40 & 3.35 \\
\hline C18orf17 & Chromosome 18 open reading frame 17 & NM_153211 & 1.27 & 3.33 \\
\hline \multicolumn{5}{|c|}{ Down-regulated genes in the recovery group } \\
\hline$R G S 4$ & Regulator of G-protein signaling 4 & NM_001102445 & -3.25 & -5.20 \\
\hline DPP10 & Dipeptidyl-peptidase 10 & NM_001004360 & -1.42 & -4.64 \\
\hline DNAJC6 & DnaJ (Hsp40) homolog, subfamily C, member 6 & NM_014787 & -0.67 & -4.61 \\
\hline NTRK2 & Neurotrophic tyrosine kinase, receptor, type 2 & NM_001007097 & -0.85 & -4.32 \\
\hline DNAJC10 & DnaJ (Hsp40) homolog, subfamily C, member 10 & NM_018981 & -3.90 & -4.03 \\
\hline$H L A-D P A 1$ & Major histocompatibility complex, class II, DP alpha 1 & NM_033554 & -1.64 & -3.87 \\
\hline C11orf54 & Chromosome 11 open reading frame 54 & NM_014039 & 0.08 & -3.85 \\
\hline$G A S 2 L 3$ & Growth arrest-specific 2 like 3 & NM_174942 & -2.55 & -3.84 \\
\hline 1560395_at & Homo sapiens, clone IMAGE:4293443, mRNA & - & -2.39 & -3.81 \\
\hline FAM55C & Family with sequence similarity 55 , member $\mathrm{C}$ & NM_145037 & 0.27 & -3.62 \\
\hline 229318_at & CDNA clone IMAGE:4814437 & - & -2.92 & -3.44 \\
\hline SPATA22 & Spermatogenesis-associated 22 & NM_032598 & -2.50 & -3.35 \\
\hline 243302_at & Transcribed locus & - & -3.53 & -3.33 \\
\hline 1563397_at & EST from clone 114659 , full insert & - & -1.86 & -3.33 \\
\hline ZNF483 & Zinc finger protein 483 & NM_001007169 & -1.42 & -3.31 \\
\hline RICTOR & Rapamycin-insensitive companion of mTOR & NM_152756 & -3.59 & -3.29 \\
\hline 244282_at & Transcribed locus & - & -1.25 & -3.24 \\
\hline 234650_at & CDNA: FLJ21254 fis, clone COL01317 & - & -2.57 & -3.23 \\
\hline 240594_at & Transcribed locus & - & -3.30 & -3.21 \\
\hline$C Y P 26 B 1$ & Cytochrome P450, family 26 , subfamily B, polypeptide 1 & NM_019885 & -3.06 & -3.19 \\
\hline
\end{tabular}

Fold change was calculated with relative average value of two arrays in each group comparing to corresponding controls, and values were represented with $\log 2$

regulated. The common genes included $C H I 3 L 1, G M 2 A$, RARRES1, CTSK, DDHD1, and CTSB. Among these, six genes that ranked high as either up-regulated or down- regulated genes were selected for real-time PCR to confirm gene expression (Fig. 4). Among the up-regulated lung genes from the monkey exposure group, CHI3L1, 
Table 3 Functional classification of differentially expressed genes in the welding fume exposure or recovery group

\begin{tabular}{|c|c|c|c|c|c|}
\hline \multicolumn{3}{|l|}{ Exposure } & \multicolumn{3}{|l|}{ Recovery } \\
\hline Functions & $P$-value & $\begin{array}{l}\text { No. of } \\
\text { genes }\end{array}$ & Functions & $P$-value & $\begin{array}{l}\text { No. of } \\
\text { genes }\end{array}$ \\
\hline \multicolumn{6}{|l|}{ Disease and disorder } \\
\hline Immunological disease & $1.24 \mathrm{E}-05-1.32 \mathrm{E}-02$ & 58 & Cancer & $1.55 \mathrm{E}-05-2.06 \mathrm{E}-02$ & 109 \\
\hline Genetic disorder & $2.19 \mathrm{E}-05-1.48 \mathrm{E}-02$ & 152 & Immunological disease & $3.40 \mathrm{E}-05-2.06 \mathrm{E}-02$ & 41 \\
\hline Cancer & $5.55 \mathrm{E}-05-1.41 \mathrm{E}-02$ & 148 & Inflammatory disease & $2.52 \mathrm{E}-04-2.06 \mathrm{E}-02$ & 45 \\
\hline $\begin{array}{l}\text { Organismal injury and } \\
\text { abnormalities }\end{array}$ & $5.65 \mathrm{E}-05-1.35 \mathrm{E}-02$ & 27 & Renal and urological disease & $2.62 \mathrm{E}-04-2.06 \mathrm{E}-02$ & 10 \\
\hline Inflammatory disease & $1.06 \mathrm{E}-04-1.48 \mathrm{E}-02$ & 59 & Reproductive system disease & $3.27 \mathrm{E}-04-2.06 \mathrm{E}-02$ & 45 \\
\hline \multicolumn{6}{|l|}{ Molecular and cellular functions } \\
\hline Cellular growth and proliferation & $3.82 \mathrm{E}-08-1.35 \mathrm{E}-02$ & 129 & $\begin{array}{l}\text { Cellular growth and } \\
\text { proliferation }\end{array}$ & $1.84 \mathrm{E}-06-2.06 \mathrm{E}-02$ & 93 \\
\hline Cellular development & $1.20 \mathrm{E}-06-1.35 \mathrm{E}-02$ & 105 & Cell cycle & 7.30E-06-2.06E-02 & 38 \\
\hline Post-translational modification & $8.86 \mathrm{E}-06-1.38 \mathrm{E}-02$ & 43 & Cell death & $1.55 \mathrm{E}-05-2.06 \mathrm{E}-02$ & 74 \\
\hline Cellular function and maintenance & $1.16 \mathrm{E}-05-1.40 \mathrm{E}-02$ & 22 & Cell morphology & $2.74 \mathrm{E}-05-2.06 \mathrm{E}-02$ & 58 \\
\hline Cell cycle & $2.22 \mathrm{E}-05-1.49 \mathrm{E}-02$ & 52 & Cellular development & $1.56 \mathrm{E}-04-2.06 \mathrm{E}-02$ & 67 \\
\hline
\end{tabular}

Top functional categories for differentially expressed genes are presented for the exposure and recovery groups. $P$-values were calculated by comparing the number of molecules of interest relative to the total number of occurrences of these molecules in all functional annotations stored in the Ingenuity Pathways knowledge base (Fisher's exact test with $P$-value adjusted using the Benjamin-Hochberg multiple testing correction)

RARRES1, DDHD1, and CTSB were all up-regulated, but $G M 2 A$ was down-regulated in rat lungs from the welding fume exposure group. However, selected down-regulated genes such as GRAP, CYPIB1, PTGFRN ID4, and NRGN in monkey lungs from the microarray analysis were all down-regulated in both monkey and rat samples. This overall result indicated that gene expression patterns detected from the microarray experiment were almost consistent with those determined from real-time PCR, and selected genes were consistently deregulated in rat samples.

\section{Discussion}

In this study, we analyzed the gene expression profiles from monkey lungs injured by welding fumes for 229 days and recovered for 153 days. Welding fumes consist of particulate matter from the heavy metal materials and gases, such as ozone. The $\mathrm{Cr}(\mathrm{VI})$ and nitrous fumes can include $\mathrm{Fe}, \mathrm{Mn}, \mathrm{Ni}, \mathrm{Cr}, \mathrm{SiO}_{2}$, and asbestos (Antonini et al. 2004; Yu et al. 2001). Several studies have investigated the toxicological effects of welding fume exposure in various animal models (Hicks et al. 1983; Kalliomäki et al. 1986, Uemitsu et al. 1984). Gene expression changes should be triggered in target tissues by welding fume exposure, so microarray analysis is a useful tool for elucidating the molecular response to welding fume exposure. Rim et al.
(2004, 2007) previously reported gene expression profiling of peripheral mononuclear cells from welding fumeexposed rats and welders. Gene expression profiling using blood samples could be useful to monitor the toxicological effects in surrogate tissues, but it is still of limited value in understanding dynamic phenomena, including lung inflammation or a response process in a target tissue. Actually, there were almost no genes consistently expressed in rat lungs (Oh et al. 2007) when compared with those expressed in rat blood after welding fume exposure (Rim et al. 2004). Furthermore, the use of a rodent model to predict toxic effects in humans also has limitations because of interspecies differences in toxicological responses, although central physiological functions are assumed to be almost common among mammals. For this reason, we used the monkey model to investigate gene expression profiling following welding fume exposure.

The histopathology showed that welding fumes were deposited within the lung tissues of monkeys, but there was no serious immune reaction. In a previous study, inflammation and infiltration of large numbers of immune cells into the alveoli were observed in a rat model following a 30-day welding fume exposure, and the lung almost recovered during a 30-day recovery period (Oh et al. 2007, 2009). These histological differences in welding fume exposure between monkeys and rats may have been caused by differences in breathing volumes of the animals, the respiration rate, and the actual exposed concentration of 
Table 4 Top-regulated genes related to inflammation in monkey lungs

\begin{tabular}{|c|c|c|c|c|c|c|}
\hline \multirow[t]{3}{*}{ Gene_symbol } & \multirow[t]{3}{*}{ Gene_title } & \multirow[t]{3}{*}{ RefSeq ID } & \multicolumn{4}{|c|}{ Fold change (Log 2) } \\
\hline & & & \multicolumn{2}{|l|}{ Exp } & \multicolumn{2}{|l|}{ Rec } \\
\hline & & & $\mathrm{T} 1$ & $\mathrm{~T} 2$ & $\mathrm{~T} 1$ & $\mathrm{~T} 2$ \\
\hline \multicolumn{7}{|c|}{ Up-regulated genes } \\
\hline$P P I D$ & Cyclophilin-40 & NM_005038 & 0.59 & 2.62 & -0.39 & -1.45 \\
\hline$I N S R$ & Insulin receptor & NM_000208 & 1.90 & 2.55 & -1.22 & -0.94 \\
\hline CPT1A & Carnitine palmitoyltransferase 1A (liver) & NM_001031847 & 1.67 & 2.17 & 2.93 & 3.63 \\
\hline$A L A S 2$ & Aminolevulinate, delta-, synthase 2 & NM_000032 & 0.53 & 1.63 & -0.84 & -0.26 \\
\hline CFLAR & I-FLICE isoform 5 & NM_001127183 & 2.79 & 1.46 & 1.95 & 1.18 \\
\hline$C D K 2$ & Cyclin-dependent kinase 2 & NM_001798 & 1.05 & 1.43 & -1.17 & -0.49 \\
\hline CPT1A & Carnitine palmitoyltransferase 1A (liver) & NM_001031847 & 0.83 & 1.39 & 0.64 & 0.74 \\
\hline$F 2 R L 1$ & Coagulation factor II (thrombin) receptor-like 1 & NM_005242 & 0.26 & 1.18 & -0.40 & -0.06 \\
\hline$P D E 4 D$ & Phosphodiesterase 4D, cAMP-specific & NM_001104631 & -0.03 & 1.00 & -0.50 & -0.22 \\
\hline INSR & Insulin receptor & NM_000208 & 1.14 & 0.57 & 1.04 & 0.97 \\
\hline \multicolumn{7}{|c|}{ Down-regulated genes } \\
\hline$K L K B 1$ & Kallikrein B, plasma (Fletcher factor) 1 & NM_000892 & -0.32 & -4.30 & 0.08 & -0.57 \\
\hline ATM & Ataxia telangiectasia mutated & NM_000051 & -1.58 & -3.24 & -0.73 & -0.53 \\
\hline$R A G 1$ & Recombination activating gene 1 & NM_000448 & -0.62 & -3.20 & -2.17 & -2.51 \\
\hline UBASH3A & Ubiquitin associated and $\mathrm{SH} 3$ domain containing, A & NM_001001895 & -1.05 & -3.19 & 1.04 & -0.45 \\
\hline$I G K C$ & Immunoglobulin kappa constant & XM_001713938 & 0.22 & -3.13 & -1.44 & -1.48 \\
\hline MAPK13 & Mitogen-activated protein kinase 13 & NM_002754 & -1.62 & -2.97 & 1.09 & 1.49 \\
\hline$P T P N 22$ & Protein tyrosine phosphatase, non-receptor type 22 & NM_012411 & -0.32 & -2.93 & -1.37 & -0.39 \\
\hline MED7 & Mediator complex subunit 7 & NM_001100816 & -1.52 & -2.64 & 1.26 & 1.11 \\
\hline IGL@ & Immunoglobulin lambda locus & - & 2.88 & -2.37 & 0.89 & 0.57 \\
\hline IFIHI & Interferon induced with helicase $\mathrm{C}$ domain 1 & NM_022168 & -1.48 & -2.37 & -0.58 & -0.26 \\
\hline
\end{tabular}

Fold change was calculated with a relative average value of two arrays in each group, compared with the corresponding controls

Values presented are $\log 2$ transformed

welding fumes. In this study, exposure concentration of welding fumes was almost similar but the duration of welding fume exposure was different between monkey and rat models as follows: monkey model was exposed to $62.5 \pm 2.7 \mathrm{mg} / \mathrm{m}^{3}$ (T2 dose) for 229 days, and rats were exposed to $84.63 \pm 2.87 \mathrm{mg} / \mathrm{m}^{3}$ (T2 dose) for 30 days. Based on the respiratory rate between monkey (appx. $2,088 \mathrm{ml} / \mathrm{min}$ ) and rat (appx. $264 \mathrm{ml} / \mathrm{min}$ ) models, actual exposed concentration was estimated as previously described by Lawson (1998) and Authier et al. (2009). The actual exposed concentration was determined with $4.23 \mathrm{mg} / \mathrm{kg} / \mathrm{day}$ and $9.68 \mathrm{mg} / \mathrm{kg} /$ day in monkey and rat models, respectively. Considering the duration of welding fume exposure, it was suggested that monkey was exposed to enough welding fumes, but welding fume accumulation in lungs has not been severe comparing to rat model. Moreover, in the monkey model, welding fumes were hardly removed from the lung after the 153-day recovery period. It seems that lung recovery or removal of welding fumes may be differently regulated in monkeys than rats. It was expected that we could understand and predict the molecular mechanism underlying welding fume exposure and the recovery process in humans using gene expression profiling in monkeys.

In the microarray analysis, the top-ranked differentially expressed genes involved in the inflammatory response were not primarily identified in the exposure and recovery groups of monkey lung, which differed from the many immune response genes identified in the rats investigated previously (Oh et al. 2007). However, a biofunctional analysis of all of the differentially expressed genes showed that about 50 genes identified in the exposure and recovery groups, respectively, appeared to be primarily involved in immunological disease. Table 4 represented that top-regulated genes related to inflammation in exposure or recovery group. Through analysis of expression changes for a total of 50 genes related to inflammation in exposure group comparing to recovery group, we found that about $50 \%$ of genes in $\mathrm{T} 2$ group were consistently up- or downregulated in both exposure and recovery groups. This result 


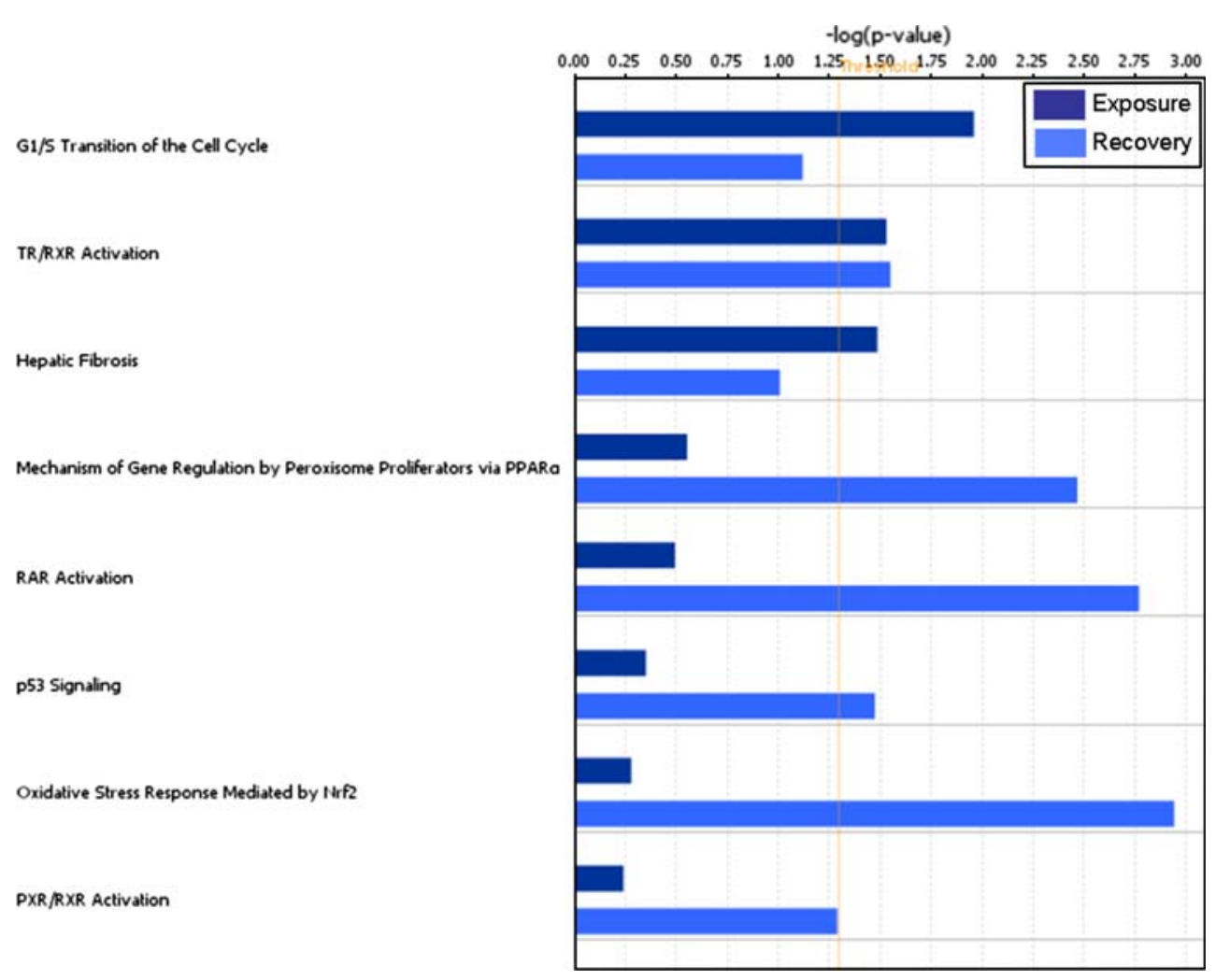

Fig. 3 Toxicological functional analysis of differentially expressed genes in the exposure and recovery groups. Interesting categories of mode of action were selected and represented. The dark blue and light blue bars in the histogram indicate the exposure and recovery groups, respectively

suggests that a significant inflammatory response did not occur in the lungs of welding fume-exposed monkeys but that inflammatory response was also progressed during recovery period.

Interestingly, there was a greater up-regulation of genes related to immunological disease in the recovery group than in the exposure group. The histopathology revealed that welding fumes were not removed during the 153-day recovery period, and it is thought that an inflammatory response increasingly progressed during the recovery period. Gene alterations involved in the immune response during the welding fume exposure and recovery periods were consistent with our histopathological observations. This result illustrates the utility of microarray analysis in characterizing responses to lung injury in monkeys exposed to welding fumes.

Here, we analyzed the changes in gene expression in the lungs of monkeys after welding fume exposure and recovery, but the number of individuals in each group was small. For this reason, we compared the differentially expressed genes identified in the present study with those identified in welding fume-exposed rats, which were previously reported (Oh et al. 2007). Among the commonly deregulated genes in the monkey and rat after welding fume exposure,
CHI3L1, CTSK, and CTSB were up-regulated, whereas GRAP, CYP1B1, CYP26B1, and ID4 were down-regulated, and the transcriptional alterations were also confirmed by real-time PCR. Transcriptional expression of $C H I 3 L 1$ is regulated by $T N F$ or $I L I B$ and $C H I 3 L 1$, which are involved in macrophage differentiation (Recklies et al. 2005; Rehli et al. 2003). CHI3L1 may play an important role in the early immune response in both monkeys and rats after exposure to welding fumes. Cathepsin $\mathrm{K}(C T S K)$, which is expressed in breast cancers, is also involved in the dendritic cell or macrophage signaling pathway and is also associated with differentiation in a leukemia cell line (Takeshita and Ishii 2008; Hattori et al. 2007). Additionally, cathepsin B $(C T S B)$, which was up-regulated during welding fume exposure, is associated with apoptosis and proliferation in various cell lines, including lung cancer and fibroblast cell lines (Moubarak et al. 2007; Bröker et al. 2004). GRAP, which was down-regulated during welding fume exposure, plays a role in negatively regulating the proliferation of lymphocyte interleukin-2 induction (Shen et al. 2002). $C Y P 1 B 1$ and $C Y P 26 B 1$ were highly down-regulated during welding fume exposure.

To date, studies about xenobiotic metabolism induced by welding fume exposure are limited, and the mechanisms 
Table 5 Commonly deregulated genes in the monkey and rat welding fume exposure groups

\begin{tabular}{|c|c|c|c|c|c|c|c|}
\hline \multirow[t]{3}{*}{ Gene_symbol } & \multirow[t]{3}{*}{ Gene_title } & \multicolumn{2}{|l|}{ RefSeq ID } & \multicolumn{4}{|c|}{ Fold change (Log 2) } \\
\hline & & \multirow[t]{2}{*}{ Monkey } & \multirow[t]{2}{*}{ Rat } & \multicolumn{2}{|c|}{ Monkey } & \multicolumn{2}{|l|}{ Rat $^{\mathrm{a}}$} \\
\hline & & & & $\mathrm{T} 1$ & $\mathrm{~T} 2$ & $\mathrm{~T} 1$ & $\mathrm{~T} 2$ \\
\hline \multicolumn{8}{|c|}{ Up-regulated genes } \\
\hline CHI3L1 & Chitinase 3-like 1 (cartilage glycoprotein-39) & NM_001276 & NM_053560 & 4.24 & 2.67 & 1.02 & 1.4 \\
\hline$G M 2 A$ & GM2 ganglioside activator & NM_000405 & NM_172335 & 1.12 & 1.55 & 0.59 & 0.58 \\
\hline RARRES1 & Retinoic acid receptor responder (tazarotene induced) 1 & NM_002888 & NM_001014790 & 1.81 & 1.53 & 1.50 & 2.10 \\
\hline CTSK & Cathepsin $\mathrm{K}$ & NM_000396 & NM_031560 & 1.28 & 1.41 & 1.37 & 1.37 \\
\hline DDHD1 & DDHD domain containing 1 & NM_030637 & NM_001033066 & 1.61 & 0.96 & 0.52 & 0.68 \\
\hline$C T S B$ & Cathepsin B & NM_001908 & NM_022597 & 1.03 & 0.77 & 0.57 & 0.86 \\
\hline \multicolumn{8}{|c|}{ Down-regulated genes } \\
\hline GRAP & GRB2-related adaptor protein & NM_006613 & NM_001025749 & -2.10 & -2.69 & -0.76 & -0.54 \\
\hline$C Y P 1 B 1$ & & NM_000104 & NM_012940 & -2.71 & -2.60 & -0.53 & -1.00 \\
\hline CYP26B1 & Cytochrome P450, family 26, subfamily B, polypeptide 1 & NM_019885 & NM_181087 & -1.23 & -1.95 & -0.66 & -0.07 \\
\hline PTGFRN & Prostaglandin F2 receptor negative regulator & NM_020440 & NM_019243 & -1.63 & -1.91 & -0.59 & -0.55 \\
\hline ID4 & $\begin{array}{l}\text { Inhibitor of DNA-binding 4, dominant negative helix-loop-helix } \\
\text { protein }\end{array}$ & NM_001546 & NM_175582 & -1.35 & -1.65 & -1.82 & -0.97 \\
\hline$N R G N$ & Neurogranin (protein kinase $\mathrm{C}$ substrate, RC3) & NM_006176 & NM_024140 & -2.51 & -1.60 & -0.71 & -0.43 \\
\hline KIDINS220 & Kinase D-interacting substrate of $220 \mathrm{kDa}$ & NM_020738 & NM_053795 & -1.08 & -1.55 & -0.38 & -0.49 \\
\hline ANK2 & Ankyrin 2, neuronal & NM_001148 & XM_001076082 & -2.15 & -1.40 & -1.01 & -1.16 \\
\hline$T M P O$ & Thymopoietin & NM_001032283 & NM_012887 & -1.31 & -1.30 & -0.39 & -0.27 \\
\hline PTGER4 & Prostaglandin E receptor 4 (subtype EP4) & NM_000958 & NM_032076 & -1.42 & -1.27 & -0.44 & -0.47 \\
\hline RHOJ & Ras homolog gene family, member $\mathrm{J}$ & NM_020663 & NM_001008320 & -1.47 & -1.27 & -0.68 & -0.62 \\
\hline CXCL12 & Chemokine (C-X-C motif) ligand 12 (stromal cell-derived factor 1 ) & NM_000609 & NM_001033882 & -1.96 & -1.25 & -0.59 & -0.18 \\
\hline$R B P 1$ & Retinol-binding protein 1 , cellular & NM_002899 & NM_012733 & -1.26 & -1.21 & -0.92 & -0.84 \\
\hline$M A M D C 2$ & MAM domain containing 2 & NM_153267 & XM_001078660 & -1.59 & -1.19 & -0.84 & -0.48 \\
\hline SPON1 & Spondin 1, extracellular matrix protein & NM_006108 & NM_172067 & -1.40 & -1.05 & -0.50 & -0.48 \\
\hline GHR & Growth hormone receptor & NM_000163 & NM_017094 & -1.20 & -1.02 & -0.86 & -1.07 \\
\hline FXYD1 & FXYD domain containing ion transport regulator 1 (phospholemman) & NM_005031 & NM_031648 & -1.26 & -0.96 & -0.93 & -0.87 \\
\hline$H P G D$ & Hydroxyprostaglandin dehydrogenase 15-(NAD) & NM_000860 & NM_024390 & -1.31 & -0.92 & -1.05 & -1.11 \\
\hline$N B L 1$ & Neuroblastoma, suppression of tumorigenicity 1 & NM_005380 & NM_031609 & -1.04 & -0.91 & -0.68 & -0.58 \\
\hline WNT5A & Wingless-type MMTV integration site family, member 5A & NM_003392 & NM_022631 & -1.14 & -0.91 & -0.72 & -1.02 \\
\hline FHL1 & Four and a half LIM domains 1 & NM_001449 & NM_001033926 & -1.11 & -0.87 & -0.58 & -0.56 \\
\hline KCNS3 & $\begin{array}{l}\text { Potassium voltage-gated channel, delayed-rectifier, subfamily S, } \\
\text { member } 3\end{array}$ & NM_002252 & NM_031778 & -1.12 & -0.73 & -0.84 & -0.56 \\
\hline SLC12A2 & $\begin{array}{l}\text { Solute carrier family } 12 \text { (sodium/potassium/chloride transporters), } \\
\text { member } 2\end{array}$ & NM_001046 & NM_031798 & -1.19 & -0.69 & -0.45 & -0.35 \\
\hline$I T P K B$ & Inositol 1,4,5-trisphosphate 3-kinase B & NM_002221 & NM_019312 & -1.09 & -0.63 & -0.86 & -0.81 \\
\hline SOX9 & $\begin{array}{l}\text { SRY (sex-determining region Y)-box } 9 \text { (campomelic dysplasia, } \\
\text { autosomal sex-reversal) }\end{array}$ & NM_000346 & XM_001081628 & -1.07 & -0.62 & -1.34 & -1.18 \\
\hline GOS2 & G0/G1switch 2 & NM_015714 & NM_001009632 & -1.03 & -0.60 & -1.02 & -0.77 \\
\hline IGFBP6 & Insulin-like growth factor binding protein 6 & NM_002178 & NM_013104 & -1.04 & -0.55 & -0.33 & -1.04 \\
\hline$R A B 28$ & RAB28, member RAS oncogene family & NM_001017979 & NM_053978 & -1.12 & -0.51 & -0.38 & -0.36 \\
\hline$G B A 2$ & Glucosidase, beta (bile acid) 2 & NM_020944 & NM_020944 & -1.18 & -0.51 & -0.49 & -0.32 \\
\hline HEY1 & Hairy/enhancer-of-split related with YRPW motif 1 & NM_001040708 & XM_001057389 & -1.05 & -0.46 & -0.50 & -0.63 \\
\hline PDLIM3 & PDZ and LIM domain 3 & NM_014476 & NM_053650 & -1.61 & -0.41 & -0.76 & -0.80 \\
\hline$H N R P D$ & Heterogeneous nuclear ribonucleoprotein D) & NM_001003810 & NM_001082539 & -2.76 & -0.30 & -0.59 & -0.39 \\
\hline RHOB & Ras homolog gene family, member B & NM_004040 & NM_022542 & -1.39 & -0.12 & -0.80 & -0.61 \\
\hline
\end{tabular}

Fold change was calculated with a relative average value of two (monkey model) or three arrays (rat model) in each group, compared with the corresponding controls. Values presented are $\log 2$ transformed

a Microarray data in the rat model were used with the permission of Oh et al. (2007). Differentially expressed genes were compared as described in the "Materials and methods". T1 dose means $31.4 \pm 2.8 \mathrm{mg} / \mathrm{m}^{3} 51.4 \pm 2.89 \mathrm{mg} / \mathrm{m}^{3}$ and T2 dose means $62.5 \pm 2.7$ and $84.63 \pm 2.87 \mathrm{mg} / \mathrm{m}^{3}$ in monkey and rat models, respectively 


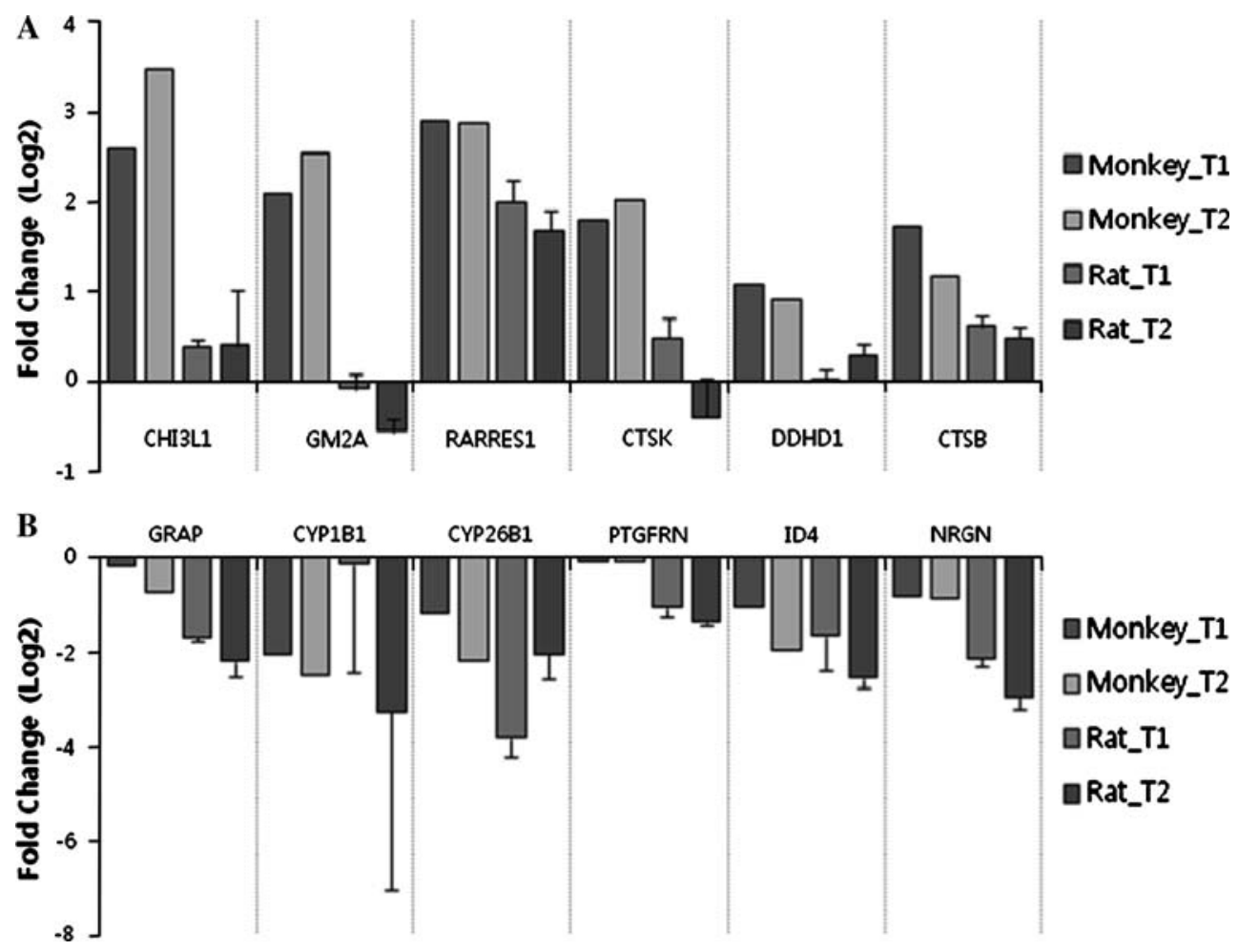

Fig. 4 Verification of top-ranked genes deregulated in monkey lung after welding fume exposure. Expression patterns of selected genes detected from the microarray experiment for monkey lung were analyzed in both the T1- and T2-dosed monkey and rat lungs by realtime PCR. a Six up-regulated genes, b Six down-regulated genes in

the welding fume exposure group of monkeys. Three independent rat samples were used to confirm the gene expression levels and average fold change. The standard deviation was calculated as described in the "Materials and methods" section

are poorly understood. However, we found that $C Y P 1 B 1$ and $C Y P 26 B 1$ were deregulated in the lung after welding fume exposure. In contrast, $I D 4$, a transcriptional regulator and inhibitor of DNA binding, was down-regulated during welding fume exposure. ID4 plays an important role in the differentiation and proliferation of neural cell and epithelial cell lines (Shan et al. 2003; Yun et al. 2004), but its involvement in lung injury and lung inflammation has not been reported.

In a previous study, genes related to the immune response, such as Mmp12 and Trem2, and many cytokines, such as $\mathrm{Cd} 5 \mathrm{l}, \mathrm{Ccl}$, and $\mathrm{Cxcl5}$, were highly expressed in rats after welding fume exposure (Oh et al. 2007). In the present study, MMP12 was not differentially expressed in monkey lung, but $M M P 9$ was up-regulated, while its expression was not altered in rats. TREM2 was consistently up-regulated in both monkeys and rats, but TREM2 was excluded from the gene list, because its gene symbol did not match during the analysis. A previous study showed that MMP12 was sensitively and significantly up-regulated by welding fume exposure. This difference in gene expression might be due to the degree of lung injury induced by welding fumes or to interspecies variability. This result also suggests that TREM2 plays an important

role in lung injury induced by welding fume exposure in both monkeys and rats. In the case of cytokine genes, $C D 5 L, C C L 7$, and $C X C L 5$ were up-regulated over 1.3 -fold or 2-fold in the recovery group but not in the exposure group, although $P$-value was not over 0.01 . Gene expression changes of these cytokines also indicate that lung injury was chronically progressed even through recovery period.

Using microarray analysis, we demonstrated, for the first time, a comprehensive gene expression profile in monkeys after welding fume exposure and recovery. We identified several genes commonly deregulated that are involved in inflammatory response and proliferation in both monkeys and rats after welding fume exposure. This information could aid in understanding the mechanisms in lung tissues after welding fume exposure.

Acknowledgments This work was supported by the Ministry of Science and Technology from the 2008 General Project grant through the International Inhalation Toxicology Evaluation Technology program at the Korea Institute of Toxicology.

Open Access This article is distributed under the terms of the Creative Commons Attribution Noncommercial License which permits any noncommercial use, distribution, and reproduction in any medium, provided the original author(s) and source are credited. 


\section{References}

Alizadeh AA, Eisen MB, Davis R et al (2000) Distinct types of diffuse large B-cell lymphoma identified by gene expression profiling. Nature 403:503-511

Antonini JM, Taylor MD, Zimmer AT et al (2003) Pulmonary responses to welding fumes: role of metal constituents welding. J Toxicol Environ Health A 67:233-249

Antonini JM, Taylor MD, Millecchia L et al (2004) Suppression in lung defenses after bacterial infection in rats pretreated with different welding fumes. Toxicol Appl Pharmacol 200:206-218

Authier S, Legaspi M, Gauvin D et al (2009) Respiratory safety pharmacology: positive control drug responses in SpragueDawley rats, Beagle dogs and cynomolgus monkeys. Regul Toxicol Pharmacol 55:229-235

Bittner M, Meltzer P, Chen Y et al (2000) Molecular classification of cutaneous malignant melanoma by gene expression profiling. Nature 406:536-540

Bröker LE, Huisman C, Span SW et al (2004) Cathepsin B mediates caspase-independent cell death induced by microtubule stabilizing agents in non-small cell lung cancer cells. Cancer Res 64:2730

Burgess WA (1995) Recognition of health hazards in industry-A review of materials and processes, 2nd edn. Wiley, New York, pp 169-179

Chung H, Hong DP, Jung JK et al (2004) Comprehensive analysis of differential gene expression profiles on carbon tetrachloride induced rat liver injury and regeneration. Toxicol Appl Pharmacol 206:27-42

El-Zein M, Malo JL, Infante-Rivard C et al (2003) Prevalence and association of welding related systemic and respiratory symptoms in welders. Occup Environ Med 60:655-661

Harris MK (2002) Welding health \& safety: a field guide for OEHS professionals. American Industrial Hygiene Association (AIHA). Fairfax, Virginia

Hattori H, Zhang X, Jia Y et al (2007) RNAi screen identifies UBE2D3 as a mediator of all-trans retinoic acid-induced cell growth arrest in human acute promyelocytic NB4 cells. Blood 110:640-650

Hicks R, Al-Shamma KJ, Lam HF et al (1983) An investigation of fibrogenic and other toxic effects of arc-welding fume particles deposited in the rat lung. J Appl Toxicol 3:297-306

ILAR (Institute for Laboratory Animal Research) (1996) Guide for the care and use of laboratory animals. National Academy Press, Washington, DC

Kalliomäki PL, Hyvärinen HK, Aitio A et al (1986) Kinetics of the metal components of intratracheally instilled stainless steel welding fume suspensions in rats. Br J Ind Med 43:112-119

Lawson PT (1998) Assistant laboratory animal technician training manual. American Association for Laboratory Animal Science, Memphis

Livak KJ, Schmittgen TD (2001) Analysis of relative gene expression data using real-time quantitative PCR and the 2(-Delta Delta $\mathrm{C}(\mathrm{T})$ ). Methods 25:402-408

Moubarak RS, Yuste VJ, Artus C et al (2007) Sequential activation of poly(ADP-ribose) polymerase 1, calpains, and Bax is essential in apoptosis-inducing factor-mediated programmed necrosis. Mol Cell Biol 27:4844-4862

Mueller EJ, Seger DL (1985) Metal fume fever-a review. Am J Emerg Med 2:271-274

NIOSH (1999) NIOSH manual of analytical methods. Method No. 7300, 7604. National Institute for Occupational Health, Cincinnati, $\mathrm{OH}$

Oda H, Fushimi F, Kato M et al (2005) Microarray analysis of the genes induced by tetracycline-regulated expression of NDRF/
NeuroD2 in P19 cells. Biochem Biophys Res Commun 335(2):458-468

Oh JH, Park HJ, Heo SH et al (2007) Gene expression analysis of lung injury in rats induced by exposure to MMA-SS welding fume for 30 days. Mol Cell Toxicol 3:306-313

Oh JH, Yang MJ, Yang YS et al (2009) Microarray-based analysis of the lung recovery process after stainless-steel welding fume exposure in Sprague-Dawley rats. Inhal Toxicol 21:347-373

Park JD, Chung YH, Kim CY et al (2007) Comparison of high MRI T1 signals with $\mathrm{Mn}$ concentration in brains of cynomolgus monkeys after $8 \mathrm{mo}$ of stainless steel welding-fume exposure. Inhal Toxicol 19:965-971

Powell CL, Kosyk O, Ross PK et al (2006) Phenotypic anchoring of acetaminophen-induced oxidative stress with gene expression profiles in rat liver. Toxicol Sci 93:213-222

Recklies AD, Ling H, White C et al (2005) Inflammatory cytokines induce production of $\mathrm{CHI} 3 \mathrm{~L} 1$ by articular chondrocytes. J Biol Chem 280:41213-41221

Rehli M, Niller HH, Ammon C et al (2003) Transcriptional regulation of $\mathrm{CHI} 3 \mathrm{~L} 1$, a marker gene for late stages of macrophage differentiation. J Biol Chem 278:44058-44067

Rim KT, Park KK, Sung JH et al (2004) Gene-expression profiling using suppression subtractive hybridization and cDNA microarray in rat mononuclear cells in response to welding-fume exposure. Toxicol Ind Health 20:77-88

Rim KT, Park KK, Kim YH et al (2007) Gene-expression profiling of human mononuclear cells from welders using cDNA microarray. J Toxicol Environ Health A 70:1264-1277

Sferlazza SJ, Beckett WS (1991) The respiratory health of welders. Am Rev Respir Dis 143:1134-1148

Shan L, Yu M, Qiu C et al (2003) Id4 regulates mammary epithelial cell growth and differentiation and is over expressed in rat mammary gland carcinomas. Am J Pathol 163:2495-2502

Shen R, Ouyang YB, Qu CK et al (2002) Grap negatively regulates T-cell receptor-elicited lymphocyte proliferation and interleukin2 induction. Mol Cell Biol 22:3230-3236

Sung JH, Kim CY, Yang SO et al (2007) Changes in 470 blood manganese concentration and MRI T1 relaxation time during 180 days of stainless steel welding-fume exposure in cynomolgus monkeys. Inhal Toxicol 19:47-55

Takeshita F, Ishii KJ (2008) Intracellular DNA sensors in immunity. Curr Opin Immunol 20:383-388

Uemitsu N, Shimizu Y, Hosokawa T et al (1984) Inhalation toxicity study of welding fumes: effect of single or repeated exposure on the lungs of rats. Toxicology 30:75-92

Wolf C, Pirich C, Valic E et al (1997) Pulmonary function and symptoms of welders. Int Arch Occup Environ Health 69:350 353

Young RR (2002) Genetic toxicology: web resources. Toxicology 173:103-121

Yu IJ, Song KS, Chang HK et al (2001) Lung fibrosis in SpragueDawley rats, induced by exposure to manual metal arc-stainless steel welding fumes. Toxicol Sci 63:99-106

Yu IJ, Song KS, Chang HK et al (2003a) Recovery from manual arcstainless steel welding-fume exposure induced lung fibrosis in Sprague-Dawley rats. Toxicol Lett 143:247-259

Yu IJ, Park JD, Park ES et al (2003b) Manganese distribution in brains of Sprague Dawley rats after 60 days of stainless steel welding fume exposure. Neurotoxicology 24:777-785

Yu IJ, Song KS, Maeng SH et al (2004) Inflammatory and genotoxic responses during 30 day welding-fume exposure period. Toxicol Lett 154:105-115

Yun K, Mantani A, Garel S et al (2004) Id4 regulates neural progenitor proliferation and differentiation in vivo. Development 131:5441-5448 